Journal for ImmunoTherapy of Cancer

\section{Fc-comprising scDb-based trivalent, bispecific $T$-cell engagers for selective killing of HER3-expressing cancer cells independent of cytokine release}

\author{
Nadine Aschmoneit, ${ }^{1}$ Lennart Kühl, ${ }^{1}$ Oliver Seifert, ${ }^{1,2}$ Roland E Kontermann (D) ${ }^{1,2}$
}

To cite: Aschmoneit N, Kühl L, Seifert 0, et al. Fc-comprising scDb-based trivalent, bispecific T-cell engagers for selective killing of HER3-expressing cancer cells independent of cytokine release. Journal for ImmunoTherapy of Cancer 2021;9:e003616. doi:10.1136/ jitc-2021-003616

- Additional supplemental material is published online only. To view, please visit the journal online (http://dx.doi.org/10. 1136/jitc-2021-003616).

Accepted 17 October 2021

Check for updates

(C) Author(s) (or their employer(s)) 2021. Re-use permitted under CC BY-NC. No commercial re-use. See rights and permissions. Published by BMJ.

${ }^{1}$ Institute of Cell Biology and Immunology, University of Stuttgart, Stuttgart, Germany ${ }^{2}$ Stuttgart Research Center Systems Biology, University of Stuttgart, Stuttgart, Germany

\section{Correspondence to} Dr Roland E Kontermann; roland.kontermann@izi.unistuttgart.de

\section{ABSTRACT}

Background Bispecific T-cell engagers are an established therapeutic strategy for the treatment of hematologic malignancies but face several challenges when it comes to their application for the treatment of solid tumors, including on-target off-tumor adverse events. Employing an avidity-mediated specificity gain by introducing an additional binding moiety for the tumor-associated antigen can be achieved using formats with a $2+1$ stoichiometry. Methods Besides biochemical characterization and validation of target cell binding to cancer cells with different HER3 expression, we used in vitro co-culture assays with human peripheral blood mononuclear cells (PBMCs) and HER3-expressing target cells to determine T-cell activation, T-cell proliferation and PBMC-mediated cancer cell lysis of HER3-positive cell lines by the trivalent, bispecific antibodies.

Results In this study, we developed trivalent, bispecific antibodies comprising a silenced Fc region for T-cell retargeting to HER3-expressing tumor cells, combining a bivalent single-chain diabody (scDb) fused to a first heterodimerizing Fc chain with either an Fab or scFv fused to a second heterodimerizing Fc chain. All these HER3targeting T-cell engagers comprising two binding sites for HER3 and one binding site for CD3 mediated target cell killing. However, format and orientation of binding sites influenced efficacy of target cell binding, target celldependent T-cell activation and T-cell-mediated target cell killing. Beneficial effects were seen when the CD3 binding site was located in the scDb moiety. These molecules showed efficient killing of medium HER3-expressing cancer cells with very low induction of cytokine release, while sparing target cells with low or undetectable HER3 expression.

Conclusion Our study demonstrates that these trivalent, bispecific antibodies represent formats with superior interdomain spacing resulting in efficient target cell killing and a potential advantageous safety profile due to very low cytokine release.

\section{BACKGROUND}

The ErbB family member HER3 has been reported to play an essential role in cancer progression, and elevated expression has been shown to correlate with worse overall survival. ${ }^{12}$ Furthermore, it has been demonstrated that upregulation of HER3 is an important resistance mechanism on epidermal growth factor receptor (EGFR) and HER2-targeted therapy. ${ }^{3-5}$ More than two dozen antibodies targeting HER3 are currently investigated in preclinical trials, ${ }^{67}$ mostly interfering with ligand binding and/ or receptor dimerization. ${ }^{8}$ However, there is still no approved treatment targeting HER3. Since monoclonal antibodies ${ }^{9} 10$ as well as therapeutic approaches involving bispecific antibodies for dual targeting of HER3 and another member of the EGFR family ${ }^{11}$ have not shown improved therapeutic activity in clinical trials, therapeutic strategies such as HER3-directed antibody-drug conjugates ${ }^{12-14}$ have been developed, uncoupling the therapeutic activity from receptor signaling.

Major histocompatibility complex (MHC)independent crosslinking of tumor cells and T-cells by bispecific antibodies represents a rapidly expanding treatment strategy in cancer therapies. ${ }^{15-17}$ Bispecific T-cell engagers are characterized by simultaneous binding of a tumor-associated antigen (TAA) and, in most cases, the CD $3 \varepsilon$ chain of the T-cell receptor (TCR)/CD3 complex, leading to the close apposition of target and effector cell resulting in activation of the T-cell. Secretion of cytokines and cytotoxic effector proteins by the T-cell eventually results in killing of the targeted tumor cell. Bispecific T-cell engagers are an established therapeutic strategy for the treatment of hematologic malignancies, for example, blinatumomab, a small bispecific T-cell engager (BiTE) targeting CD19 and CD3, approved for the treatment of acute lymphoblastic leukemia. ${ }^{18}$ However, bispecific T-cell engagers face several challenges when it comes to their application for the treatment of solid tumors, including the attack of non-tumor cells with low expression level of the TAA and/or systemic cytokine-associated 
adverse events. ${ }^{16}$ Recent studies have shown that an aviditymediated specificity gain through bivalent binding to the TAA can be achieved using novel formats with a $2+1$ stoichiometry. ${ }^{19-23}$ Additionally, formats in the $2+1$ stoichiometry circumvent unspecific or non-targeted CD3-crosslinking and T-cell activation by monovalent binding to the trigger molecule CD3 on T-cells. ${ }^{1724-26}$ We have recently demonstrated that a small trivalent, bispecific single-chain diabody (scDb)-scFv showed superior binding to target expressing tumor cells translating into more efficient target cell killing by peripheral blood mononuclear cells (PBMCs). ${ }^{27}$ Small bispecific formats such as BiTEs, ${ }^{28}$ dual-affinity re-targeting antibodies $(\mathrm{DARTs})^{29}$ and $\mathrm{scDb}^{30}$ have been reported to mediate tight contacts between target cell and T-cells due to their small size and the short distance between the two binding sites, resulting in efficient T-cell activation. However, their pharmacokinetic properties are characterized by a very short serum half-life and continuous infusion is necessary. ${ }^{3132}$

In the present study, trivalent, bispecific Fc-comprising anti-HER3 $\times$ anti-CD3 antibodies were generated by combining an scDb molecule and an scFv or Fab fragment with a silenced heterodimerizing Fc part ( $\mathrm{scDb} / \mathrm{scFv}-\mathrm{Fc}$, $\mathrm{scDb} / \mathrm{Fab}-\mathrm{Fc}){ }^{33}$ Thus, the trivalent bispecific antibodies employ bivalent binding to the TAA HER3 and monovalent binding to $\mathrm{CD} 3$, combining the favorable properties of the scDb format with improved pharmacokinetic properties due to the introduced Fc part. We analyzed the effects of the different possible geometries on target cell binding, T-cell-mediated target cell killing and T-cell activation in vitro, demonstrating that these HER3-targeting T-cell engagers efficiently mediate target cell destruction independent of cytokine release, with a superior activity observed for the $\mathrm{scDb} / \mathrm{scF}$-Fc format.

\section{MATERIALS AND METHODS Materials}

Antibodies were purchased from BioLegend (PerCP/Cy5.5 anti-human CD3, 317336; PE anti-human CCR7, 353204; APC anti-human CD45RA; 304112), Miltenyi Biotec (antihuman CD4-VioBlue, 130-097-333; anti-human CD8-PE/ Vio770, 130-096-556) or Dianova (goat IgG anti-human IgG (Fc)-RPE, 109-115-098). Human IFN- $\gamma$ DuoSet ELISA kit (DY285) and Human IL-2 DuoSet ELISA kit (DY202) were obtained from R\&D Systems. CellTrace CFSE Cell Proliferation Kit (C34554) was purchased from Thermo Fisher Scientific. FaDu, SKBR-3 and MCF-7 cells were obtained from different sources and cultured as described previously. ${ }^{34}$ LIM1215 were obtained from Merck KGaA (100923011VL) and cultured in RPMI-1640 (Thermo Fisher Scientific, 11875), 10\% fetal bovine serum (FBS) (Pan Biotech, P30-3309). Density gradient centrifugation (Lymphocyte Separation Medium 1077, PromoCell, C-44010) was used to isolate human PBMCs from buffy coats of healthy donors (Blood Bank, Klinikum Stuttgart). PBMCs were cultivated in RPMI-1640, 10\% FBS.

\section{Antibody production and purification}

Human anti-HER3 antibody $3-43^{34}$ and a humanized version of anti-CD3 $\mathrm{UCHT}^{27}$ were used to generate the different trivalent, bispecific antibodies. Genes encoding the different polypeptide chains (see figure 1) were cloned into the pSecTagAL1 vector (a modified version of pSecTagA (Invitrogen, Thermo Fisher Scientific, V90020) ) and were produced in transiently transfected HEK293-6E cells (NRC Biotechnology Research Institute, Canada) using polyethylenimine (linear, $25 \mathrm{kDa}$, Sigma-Aldrich, 764604) as described previously. ${ }^{27}$ After 96 hours of incubation at $37^{\circ} \mathrm{C}$ and $5 \% \mathrm{CO}_{2}$ shaking, supernatants were harvested and proteins were purified by Protein A affinity chromatography (Protein A Sepharose 4 Fast Flow, Pharmacia Biotech, Sweden, 17-0974-03) and subsequent size-exclusion fast protein liquid chromatography (FPLC) on a Superdex 200 10/300 GL column (phosphate-buffered saline (PBS) as mobile phase, $0.5 \mathrm{~mL} / \mathrm{min}$ flow rate).

\section{Biochemical characterization}

SDS-PAGE analysis under reducing and non-reducing conditions stained with Coomassie Brilliant Blue G-250 was used to evaluate purified proteins. Oligomerization state of the proteins was determined using Waters 2695 HPLC and a TSKgel SuperSW mAb HR column (Tosoh Bioscience) at a flow rate of $0.5 \mathrm{~mL} / \mathrm{min}$ with $0.1 \mathrm{M}$ $\mathrm{Na}_{2} \mathrm{HPO}_{4} / \mathrm{NaH}_{2} \mathrm{PO}_{4}, 0.1 \mathrm{M} \mathrm{Na}_{2} \mathrm{SO}_{4}, \mathrm{pH} 6.7$ as mobile phase. ${ }^{27}$ Thyroglobulin (669kDa, Sr $\left.8.5 \mathrm{~nm}\right), \beta$-amylase $(200 \mathrm{kDa}, \mathrm{Sr} 5.4 \mathrm{~nm})$, bovine serum albumin $(67 \mathrm{kDa}, \mathrm{Sr}$ $3.55 \mathrm{~nm})$ and carbonic anhydrase (29kDa, Sr $2.35 \mathrm{~nm})$ were used as reference proteins.

\section{Cell binding}

Target cells $\left(1 \times 10^{5}\right.$ cells/well) were incubated with a serial dilution of the trivalent, bispecific molecules in phosphate buffered saline-fetal bovine serum-sodium azide buffer (PBA; PBS, 2\% (v/v) FBS, 0.02\% (w/v) sodium azide) at $4^{\circ} \mathrm{C}$ for 1 hour. A PE-conjugated anti-human Fc antibody (Dianova) was used for detection of bound antibodies. Incubation and washing steps were performed in PBS, 2\% FBS and $0.02 \%$ sodium azide. Fluorescence was determined using MACSQuant VYB or MACSQuant Analyzer 10 (Miltenyi Biotec) and data were analyzed using FlowJo (Tree Star). Relative median fluorescence intensities (rel. MFI) were calculated as followed: relative $\mathrm{MFI}=\left(\left(\mathrm{MFI}_{\text {sample }}-\left(\mathrm{MFI}_{\text {detection }}-\mathrm{MFI}_{\text {cells }}\right)\right) / \mathrm{MFI}_{\text {cells }}\right)$.

\section{IL-2 / IFN- $\gamma$ release assay}

Previously seeded MCF-7 cells $\left(2 \times 10^{4}\right.$ cells/well $)$ were incubated with a serial dilution of the trivalent, bispecific antibodies for $15 \mathrm{~min}$ at RT and $2 \times 10^{5} \mathrm{PBMCs} /$ well (effector to target cell ratio: 10:1) were added subsequently. After 24 hours (interleukin (IL)-2) or 48 hours (interferon (IFN)- $\gamma$ ), IL-2/IFN- $\gamma$ concentration in cellfree supernatants of the co-culture assay was determined using sandwich ELISA as described previously. ${ }^{27}$ 
A

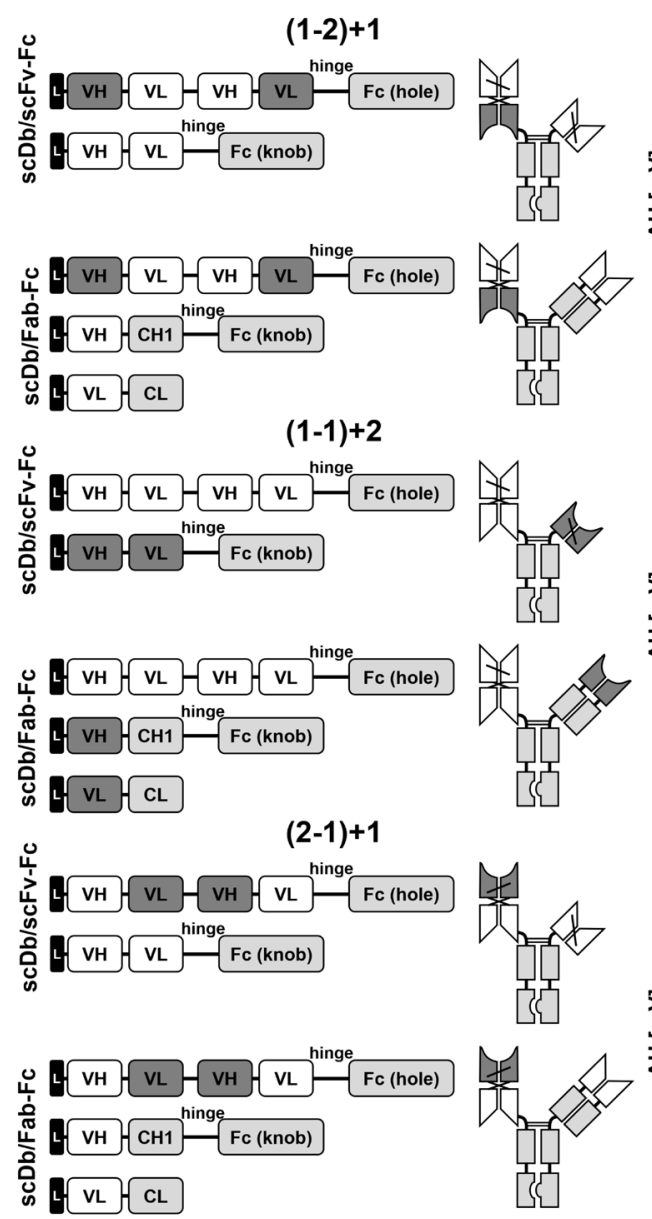

B
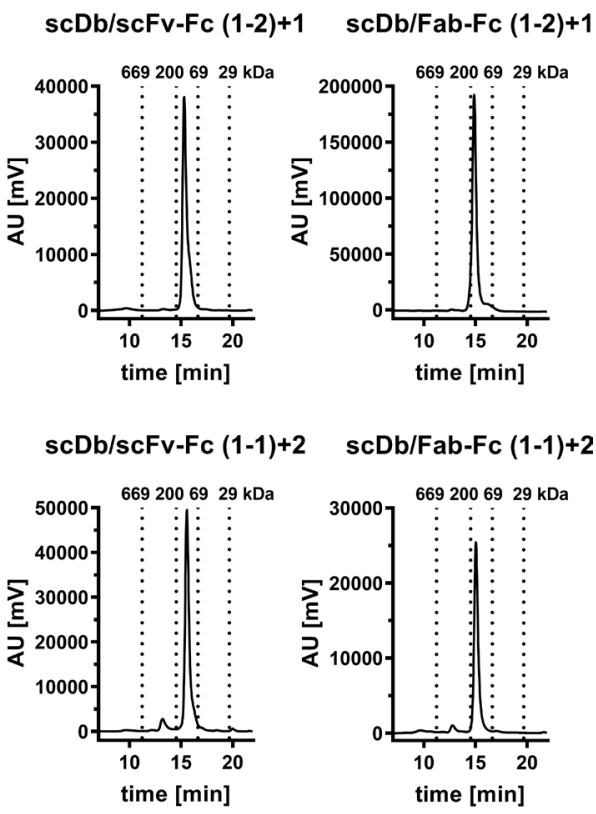

scDb/scFv-Fc (2-1)+1 scDb/Fab-Fc (2-1)+1
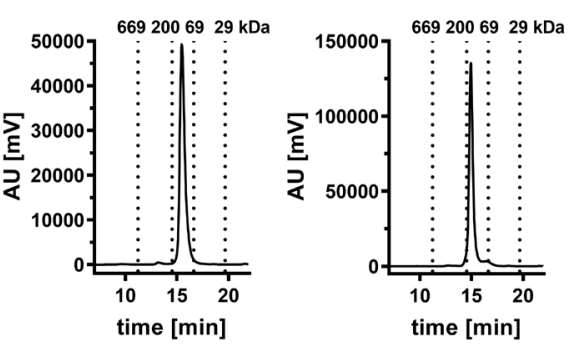

C
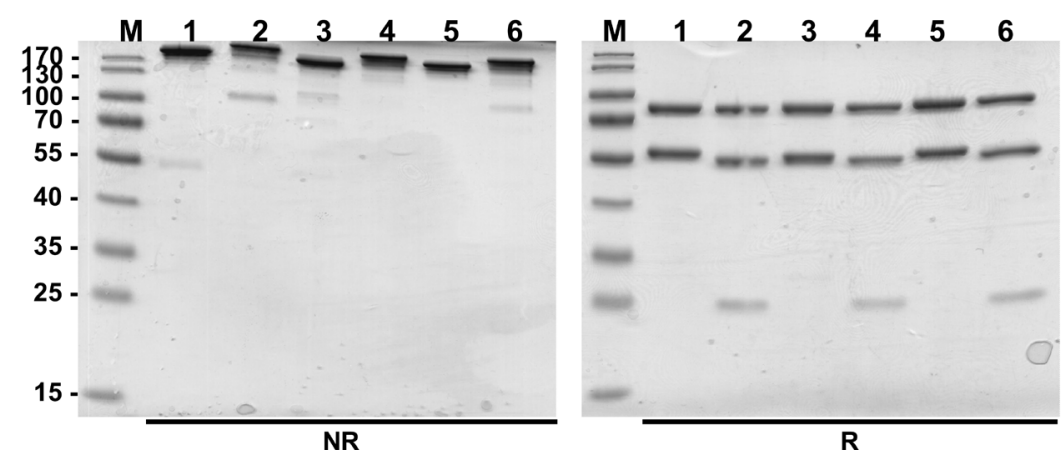

Figure 1 Biochemical characterization of scDb/scFv-Fc and scDb/Fab-Fc variants. (A) Composition and schematic illustration of trivalent, bispecific antibodies. Nomenclature: 1 refers to the HER3 binding site, 2 refers to the CD3 binding site. Numbers in brackets refer to the binding sites of the scDb moiety. Variable domains of HER3 and CD3 are shown in white and dark gray, respectively. Constant domains are shown in light gray. (B) Size-exclusion chromatography by high performance liquid chromatography using a Tosoh TSKgel SuperSW mAb HR column. (C) Sodium dodecylsulfate polyacrylamide gel electrophoreses analysis (12\% PAA, $2 \mu \mathrm{g} / \mathrm{lane}$, Coomassie blue staining) of (1) scDb/scFv-Fc (1-2)+1, (2) scDb/Fab-Fc (1-2)+1, (3) scDb/scFv-Fc $(1-1)+2$, (4) scDb/Fab-Fc (1-1)+2, (5) scDb/scFv-Fc (2-1)+1 and (6) scDb/Fab-Fc (2-1)+1 under reducing (R) and non-reducing (NR) condition. M, protein marker; $\mathrm{AU}$, arbitrary units; $\mathrm{CH} 1$, constant heavy chain domain 1; $\mathrm{CL}$, constant light chain domain; Fc, fragment crystallizable; scDb, single-chain diabody; VH, variable heavy chain domain; VL, variable light chain domain,

\section{T-cell proliferation}

PBMCs were stained with carboxyfluorescein diacetate succinimidyl ester (CFSE) at $625 \mathrm{nM} / 1 \times 10^{6}$ cells $/ \mathrm{mL}$ to analyze the proliferative effect on T-cells. ${ }^{27}$ MCF-7 cells $\left(2 \times 10^{4}\right.$ cells/well $)$ were incubated with a serial dilution of the trivalent, bispecific antibodies for $15 \mathrm{~min}$ at RT and $2 \times 10^{5}$ CFSE-labeled PBMCs/well were added subsequently. Following an incubation for 6 days at $37^{\circ} \mathrm{C}$ and $5 \% \mathrm{CO}_{2}$, fluorescence-conjugated antibodies directed against cell surface markers were used to label immune cells of interest and their proliferation was determined 
by multicolor flow cytometry analysis using MACSQuant Analyzer 10 (Miltenyi Biotec) as described previously. ${ }^{27}$

\section{Cytotoxicity}

Target cells $\left(2 \times 10^{4}\right.$ cells/well $)$ were incubated with a serial dilution of the trivalent, bispecific antibodies for $15 \mathrm{~min}$ at RT before effector cells (PBMCs) were added in an effector to target cell ratio of 10:1. ${ }^{27}$ Supernatants were discarded after 3 days of incubation at $37^{\circ} \mathrm{C}$ and $5 \%$ $\mathrm{CO}_{2}$ and target cell viability was determined using crystal violet staining. Methanol $(50 \mu \mathrm{L} /$ well $)$ was used to solve the staining and optical density measured at $550 \mathrm{~nm}$ using the Tecan spark (Tecan) as described previously. ${ }^{27}$

\section{Statistics}

All data are represented as mean \pm SD. Significances were calculated by GraphPad Prism V.7.0 and results were compared by t-test.

\section{RESULTS}

\section{Generation of bispecific antibodies}

Trivalent, bispecific antibodies comprising a silenced Fc region and directed against HER3 and CD3 were generated by combining an scDb molecule fused to a first heterodimerizing Fc chain with either an Fab or scFv fragment fused to a second heterodimerizing Fc chain. All molecules were bivalent for HER3 (referred to as ' 1 ' in the nomenclature) and monovalent for CD3 (referred to as ' 2 ' in the nomenclature). Binding sites were arranged in all three possible configurations (figure 1A).

The trivalent, bispecific antibodies were produced in transiently transfected HEK293-6E cells and purified by protein A affinity chromatography (online supplemental figure S1) followed by a preparative size-exclusion chromatography step (SEC) using FPLC to remove highmolecular and low-molecular weight species (figure 1B). Protein purity was confirmed by SDS-PAGE analysis under reducing and non-reducing conditions, revealing one band under non-reducing conditions showing correct assembly of the antibodies (figure 1C, left panel). SDSPAGE under reducing conditions revealed two bands at $\sim 80 \mathrm{kDa}$ and $\sim 56 \mathrm{kDa}$ for all $\mathrm{scDb} / \mathrm{scFv}-\mathrm{Fc}$ molecules corresponding to the calculated molecular mass of $80 \mathrm{kDa}$ for the scDb-Fc(hole) chain and $54 \mathrm{kDa}$ for the $\mathrm{scFv}-\mathrm{Fc}(\mathrm{knob})$ chain (figure $1 \mathrm{C}$, right panel). For the $\mathrm{scDb} / \mathrm{Fab}-\mathrm{Fc}$ molecules, three bands at $\sim 80 \mathrm{kDa}, \sim 55 \mathrm{kDa}$ and $\sim 25 \mathrm{kDa}$ were observed, corresponding to the scDb$\mathrm{Fc}$ (hole) $(80 \mathrm{kDa})$, the heavy chain $(\mathrm{knob})(52 \mathrm{kDa})$ and the light chain $(26 \mathrm{kDa})$ (figure $1 \mathrm{C}$, left panel). In analytical SEC, all trivalent, bispecific antibodies eluted as one major peak confirming purity and integrity of the proteins. A molecular mass of $\sim 134 \mathrm{kDa}$ for the $\mathrm{scDb} / \mathrm{scFv}-\mathrm{Fc}$ molecules and $\sim 157 \mathrm{kDa}$ for the scDb/Fab-Fc molecules was determined in accordance with the calculated molecular mass of $129 \mathrm{kDa}$ and $150 \mathrm{kDa}$, respectively (figure $1 \mathrm{~B}$ ). In summary, all six trivalent, bispecific antibody configurations could be produced in mammalian cells and assembled into intact proteins with yields between 1.2 and $16 \mathrm{mg} / \mathrm{L}$ (online supplemental table S1).

\section{Binding to HER3-expressing target cells}

A panel of cell lines expressing varying HER3 receptor levels was used to determine tumor cell binding. On the tumor cell lines LIM1215 ( 20,000 HER3/cell), MCF-7 ( 18,000 HER3/cell), SKBR-3 ( 14,000 HER3/cell) and $\mathrm{FaDu}(\sim 3000 \mathrm{HER} 3 / \mathrm{cell})$, the scDb/scFv-Fc molecules in the $(1-2)+1$ and the $(2-1)+1$ configuration (see figure 1) showed similar binding with $\mathrm{EC}_{50}$ values in the low picomolar range, while the $\mathrm{scDb} / \mathrm{scFv}-\mathrm{Fc}$ molecule in the (1-1)+2 configuration showed a 10-fold to 15-fold lower binding capacity (figure $2 \mathrm{~A}-\mathrm{D}$, table 1 ). A similar trend was observed for the scDb/Fab-Fc molecules, with a twofold to fivefold reduced binding for the (1-1)+2 configuration. No binding for all trivalent, bispecific molecules was observed on the HER3-negative cell lines HT1080 and MDA-MB-231 (figure 2E,F). All trivalent, bispecific molecules showed binding to the CD3-expressing Jurkat cell line. Here, the scDb/Fab-Fc molecules in the (1-1)+2 configuration showed sixfold reduced binding compared with the $\mathrm{scDb} / \mathrm{scFv}-\mathrm{Fc}$ in the same configuration, while all other molecules showed similar binding in the low nanomolar range (figure 2G, table 1). In summary, $\mathrm{scDb} / \mathrm{Fab}-\mathrm{Fc}$ and $\mathrm{scDb} / \mathrm{scF} v-\mathrm{Fc}$ in the (1-2)+1 and (2-1)+1 configuration showed strong binding to HER3-expressing cell lines, while both formats in the (1-1)+2 configuration showed reduced binding.

\section{Activation of effector T-cells by trivalent, bispecific molecules}

Co-culture assays were used to demonstrate simultaneous binding of the trivalent, bispecific molecules to T-cells and target cells resulting in T-cell activation. First, cytokine release (IL-2 and IFN- $\gamma$ ) was determined. No or only a marginal induction of IL-2 release was observed for all molecules (figure 3A). Similar results were obtained for the IFN- $\gamma$ release (figure 3B). An scDb directed against HER3 and $\mathrm{CD}^{27}$ was included in these experiments, showing a strong cytokine release in both assays. Next, we investigated proliferation of $\mathrm{CD}^{+}$and $\mathrm{CD} 8^{+}$T-cells. All molecules in the scDb/scFv-Fc format mediated proliferation of $\mathrm{CD}^{+}$and $\mathrm{CD} 8^{+}$T-cells. Regarding proliferation of $\mathrm{CD} 4^{+}$T-cells, superior activity was observed for the $\mathrm{scDb} / \mathrm{scFv}-\mathrm{Fc}$ format compared with the scDb/Fab-Fc format for all configurations (figure $3 \mathrm{C}$, table 2). In line with this, the $\mathrm{scDb} / \mathrm{scFv}$-Fc formats also showed higher proliferative capacity on $\mathrm{CD}^{+}$T-cells (figure 3D, table 2). However, the difference between the $\mathrm{scDb} / \mathrm{scFv}-\mathrm{Fc}$ and the $\mathrm{scDb} / \mathrm{Fab}-\mathrm{Fc}$ format was more pronounced for the $(1-2)+1$ configuration for $\mathrm{CD}^{+}$T-cell proliferation, as the $\mathrm{scDb} / \mathrm{Fab}-\mathrm{Fc}(1-2)+1$ only showed a low induction of proliferation. Additionally, the effect of the trivalent, bispecific molecules on the proliferation and the frequency of T-cell subpopulations was investigated. Treatment with the $\mathrm{scDb} / \mathrm{scF}$-Fc $(2-1)+1$ and $\mathrm{scDb} / \mathrm{Fab}-\mathrm{Fc}$ $(2-1)+1$ mainly led to proliferation of central memory $\left(\mathrm{T}_{\mathrm{CM}}\right)$ and effector memory $\left(\mathrm{T}_{\mathrm{EM}}\right) \mathrm{CD} 4^{+} \mathrm{T}$-cells (figure $4 \mathrm{~A}$, 
A

B

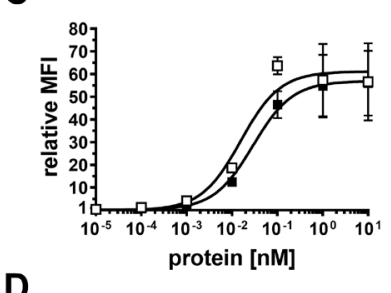

D
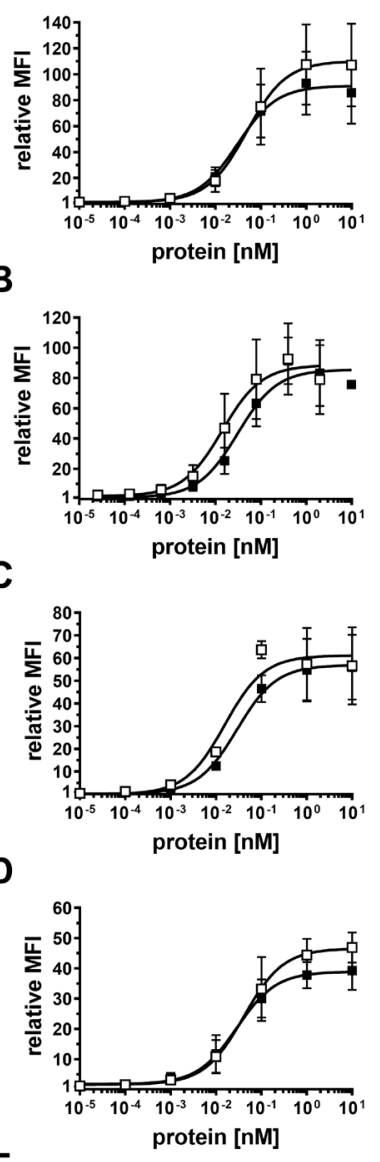

E

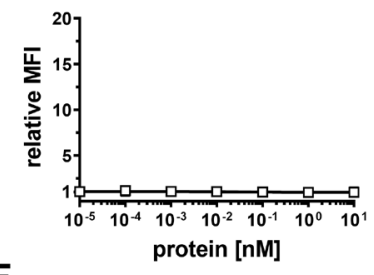

$\mathbf{F}$

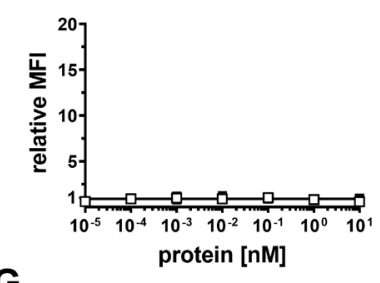

G

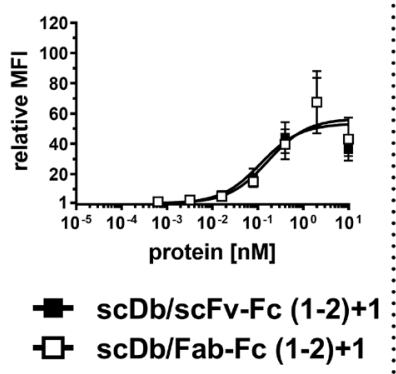

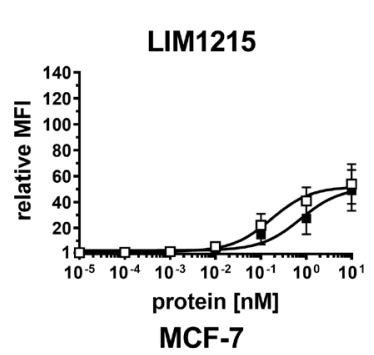
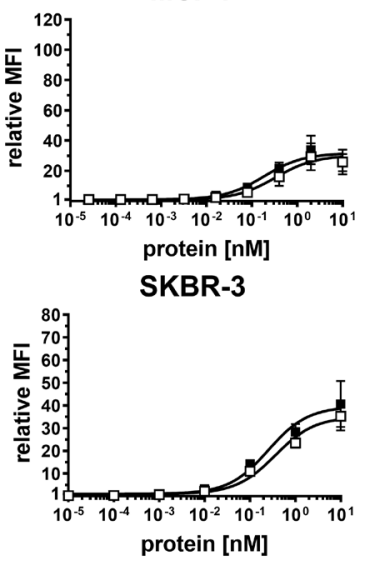

$\mathrm{FaDu}$

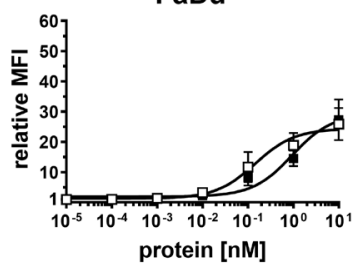

HT1080

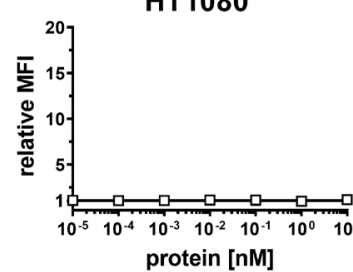

MDA-MB-231
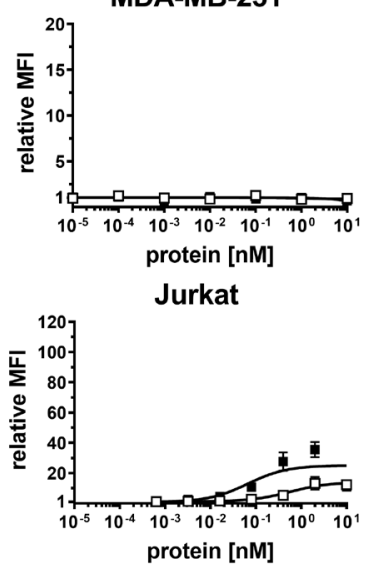

scDb/scFv-Fc (1-1)+2

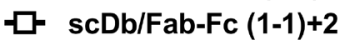

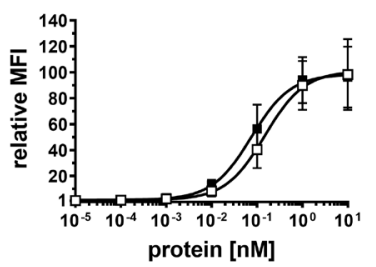
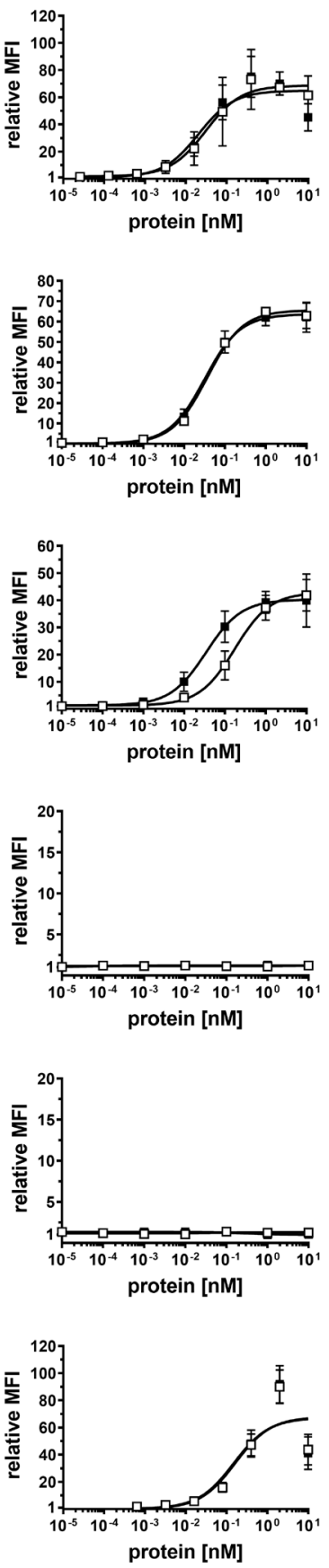

scDb/scFv-Fc (2-1)+1

scDb/Fab-Fc (2-1)+1

Figure 2 Binding properties of scDb/scFv-Fc and scDb/Fab-Fc variants. Binding to (A) LIM1215, (B) MCF-7, (C) SKBR-3, (D) FaDu, (E) HT1080, (F) MDA-MB-231 and (G) CD3-expressing Jurkat cells was analyzed in flow cytometry. A PE-labeled antihuFc mAb was used to detect bound protein. Mean $\pm S D, n=3$. MFI, median fluorescence intensities; scDb, single-chain diabody. 
Table 1 Binding to HER3-expressing tumor cells of scDb/scFv-Fc and scDb/Fab-Fc variants

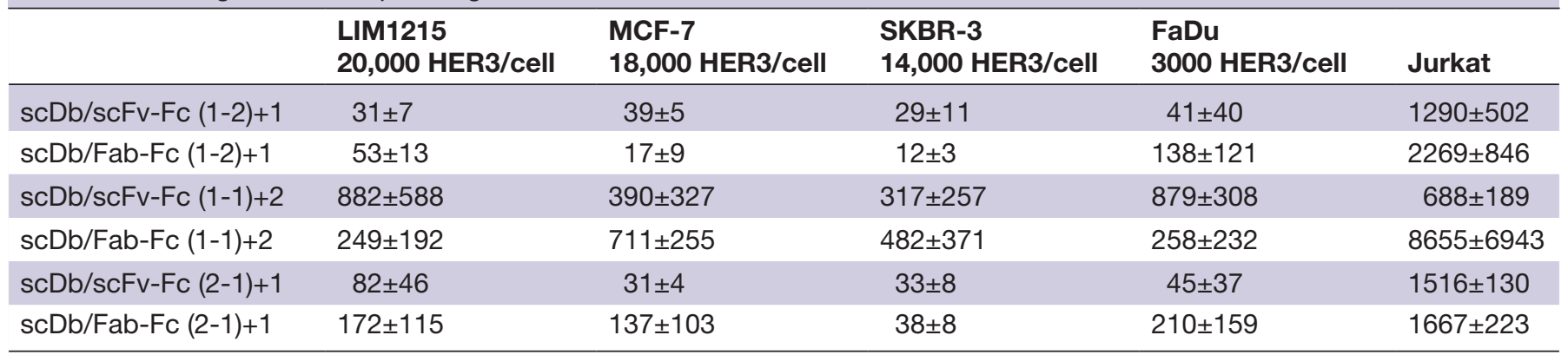

$\mathrm{EC}_{50}(\mathrm{pM})$, mean $\pm \mathrm{SD}, \mathrm{n}=3$.

$\mathrm{scDb}$, single-chain diabody.

left panel). Similar results were obtained for the $\mathrm{scDb} /$ scFv-Fc (1-2)+1. However, the scDb/Fab-Fc (1-2)+1 mainly induced proliferation of naive $\left(\mathrm{T}_{\mathrm{N}}\right) \mathrm{CD}^{+} \mathrm{T}$-cells. Low to no proliferation was observed for the two molecules in the $(1-1)+2$ configuration. Similarly, treatment with the $\mathrm{scDb} / \mathrm{scFv}-\mathrm{Fc}(1-2)+1, \mathrm{scDb} / \mathrm{scFv}-\mathrm{Fc}(2-1)+1$ and $\mathrm{scDb} /$

A
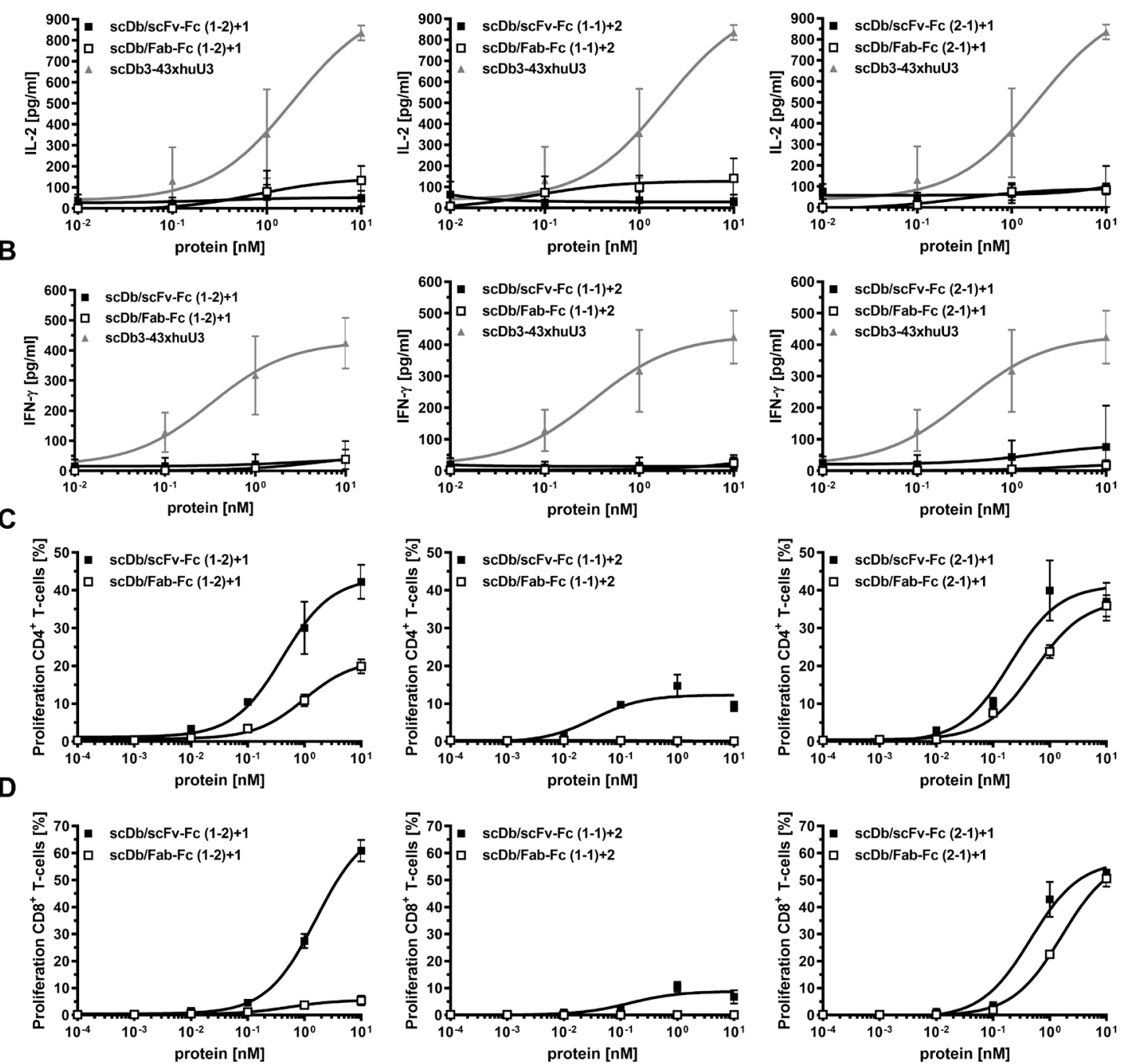

Figure 3 Activity of scDb/scFv-Fc or scDb/Fab-Fc variants on cytokine release, T-cell activation and proliferation. (A) IL-2 and (B) IFN- $\gamma$ release mediated by scDb/scFv-Fc or scDb/Fab-Fc variants. Peripheral blood mononuclear cells were co-cultured with MCF-7 cells in the presence of a serial dilution of the scDb/scFv-Fc or scDb/Fab-Fc variants. Cytokine release was determined after 24 hours (IL-2) or 48 hours (IFN- $\gamma$ ) using sandwich ELISA. Proliferation of (C) CD4 ${ }^{+}$and (D) CD8 ${ }^{+}$T-cells was measured by carboxyfluorescein diacetate succinimidyl ester dilution in flow cytometry. Mean $\pm \mathrm{SD}, \mathrm{n}=3$. IFN- $\gamma$, interferon- $\gamma$; IL-2, interleukin 2 ; scDb, single-chain diabody. 
Table 2 T-cell proliferation mediated by scDb/scFv-Fc and scDb/Fab-Fc variants

\begin{tabular}{lcc}
\hline & Proliferation of CD4 ${ }^{+}$T-cells & Proliferation of CD8 $^{+}$T-cells $^{-}$ \\
\hline scDb/scFv-Fc (1-2)+1 & $599 \pm 546$ & $1627 \pm 375$ \\
scDb/Fab-Fc (1-2)+1 & $1075 \pm 461$ & $564 \pm 335$ \\
scDb/scFv-Fc (1-1)+2 & $34 \pm 8$ & $144 \pm 70$ \\
scDb/Fab-Fc (1-1)+2 & & - \\
scDb/scFv-Fc (2-1)+1 & $209 \pm 45$ & $497 \pm 182$ \\
scDb/Fab-Fc (2-1)+1 & $546 \pm 150$ & $1652 \pm 363$ \\
\hline
\end{tabular}

$\mathrm{EC}_{50}(\mathrm{pM})$, mean $\pm \mathrm{SD}, \mathrm{n}=3$.

$\mathrm{scDb}$, single-chain diabody.

Fab-Fc (2-1)+1 mainly led to the proliferation of $\mathrm{T}_{\mathrm{CM}}$ and $\mathrm{T}_{\mathrm{FM}} \mathrm{CD}^{+} \mathrm{T}$-cells. Regarding the frequency of T-cell subtypes, no differences for the $\mathrm{CD} 4^{+} \mathrm{T}$-cells was observed. However, scDb/Fab-Fc (1-2)+1 and scDb/scFv-Fc (1-1)+2 mediated an increased frequency of $\mathrm{CD}^{+}$effector T-cells, while all other molecules shifted the population toward $\mathrm{CD}^{+}$effector memory T-cells (figure 4B). In summary, the $\mathrm{scDb} / \mathrm{scFv}-\mathrm{Fc}$ molecules were more potent in mediating proliferation of T-cells compared with the $\mathrm{scDb} /$ Fab-Fc format with a low or neglectable induction of cytokine release for all trivalent, bispecific molecules.
Cancer cell lysis of HER3-positive cell lines by trivalent, bispecific antibodies

Cell lines with medium (LIM1215, MCF-7, SKBR-3), low (FaDu) and undetectable (HT1080, MDA-MB-231) HER3 expression were used to determine the cytotoxic effects of PBMCs on target cells mediated by the trivalent, bispecific antibodies. All trivalent, bispecific antibodies in the $(1-2)+1$ and $(2-1)+1$ configuration were able to redirect unstimulated PBMCs to lyse target cells with medium HER3 expression in a concentration-dependent manner. Regarding potency $\left(\mathrm{EC}_{50}\right.$ value in cell killing), $\mathrm{scDb} /$

A
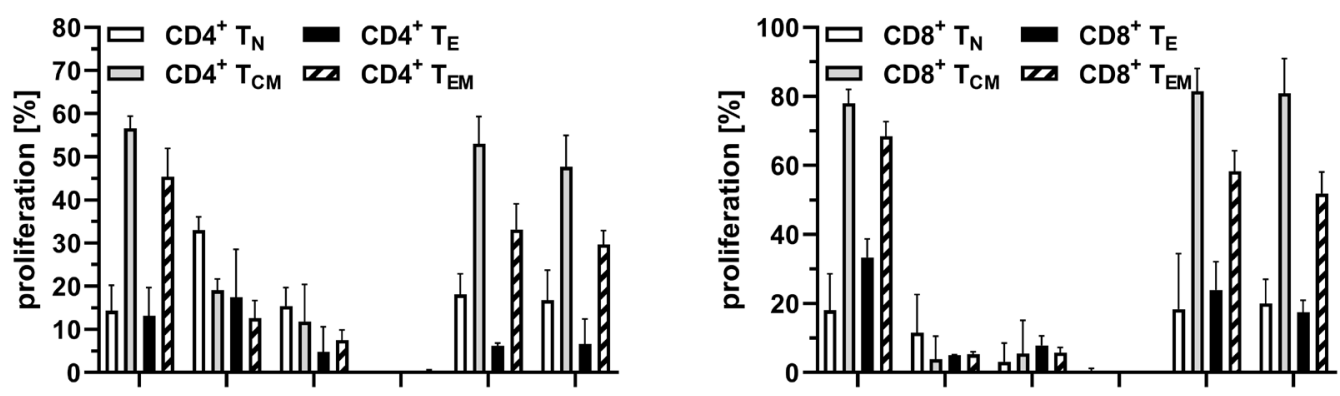

B
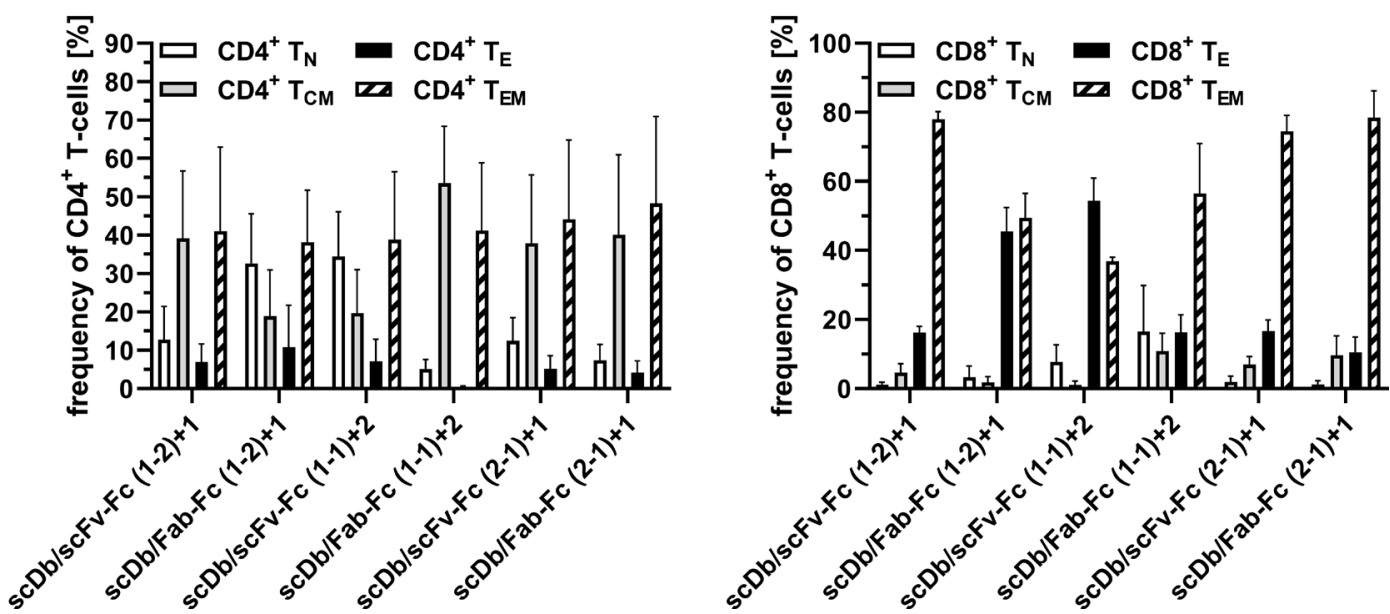

Figure 4 Activity of scDb/scFv-Fc or scDb/Fab-Fc variants on proliferation and composition of T-cell subpopulations. (A) Proliferation of naive $\left(T_{N}, C D 45 R A^{+}, C C R 7^{+}\right)$, central memory $\left(T_{C M}, C D 45 R A^{-}, C C R 7^{+}\right)$, effector $\left(T_{E}, C D 45 R A^{+}, C C R 7^{-}\right)$ and effector memory $\left(\mathrm{T}_{\mathrm{EM}}, \mathrm{CD} \mathrm{R} \mathrm{RA}^{-}, \mathrm{CCR}^{-}\right)$subpopulations of $\mathrm{CD} 4^{+} \mathrm{T}$-cells and $\mathrm{CD} 8^{+} \mathrm{T}$-cells was determined by carboxyfluorescein diacetate succinimidyl ester dilution in flow cytometry. (B) Composition of $\mathrm{CD} 4^{+}$and $\mathrm{CD} 8^{+} \mathrm{T}$-cell subpopulation was measured in flow cytometry. Mean $\pm S D, n=3$. scDb, single-chain diabody. 


\section{A}

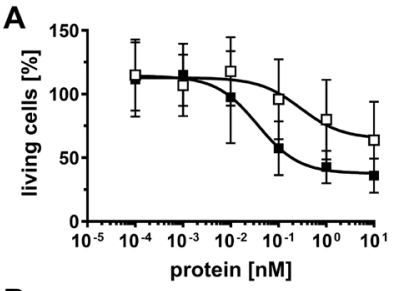

B

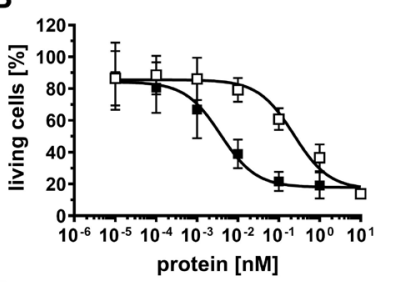

C

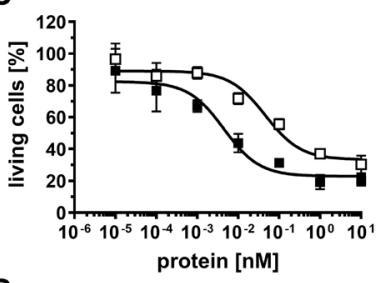

D

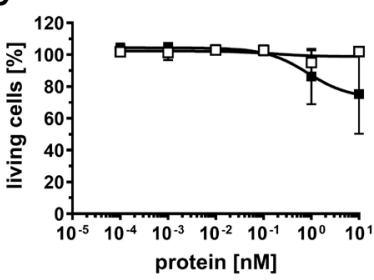

E

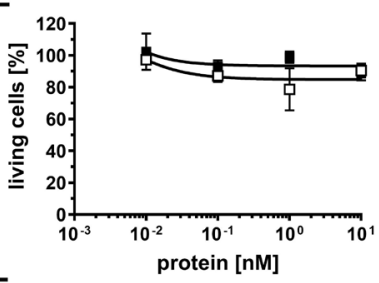

F

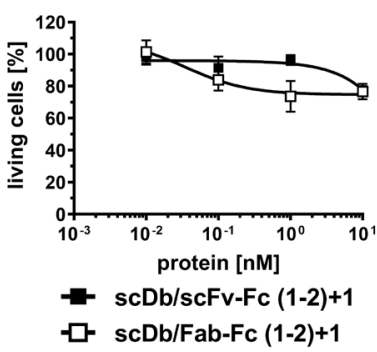

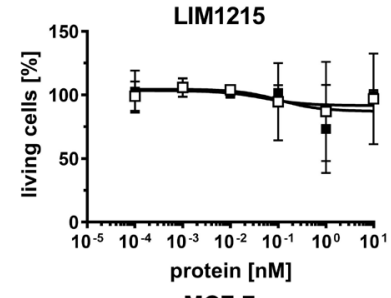

MCF-7

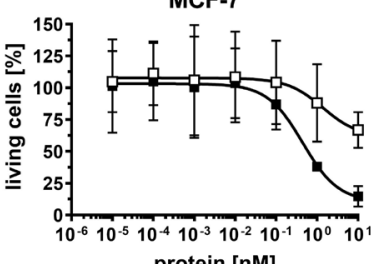

protein $[\mathrm{nM}]$

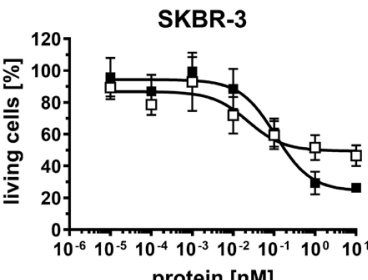

protein [nM]

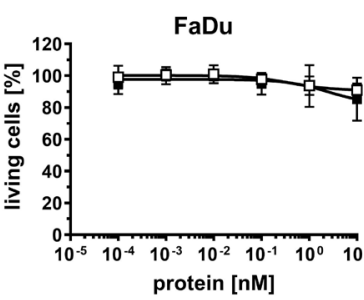

HT1080

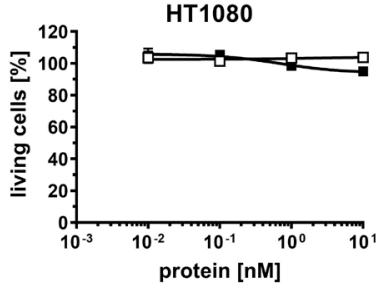

Prots

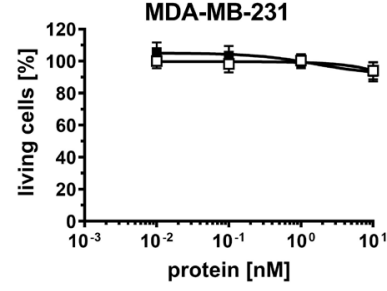

scDb/scFv-Fc (1-1)+2

scDb/Fab-Fc (1-1)+2
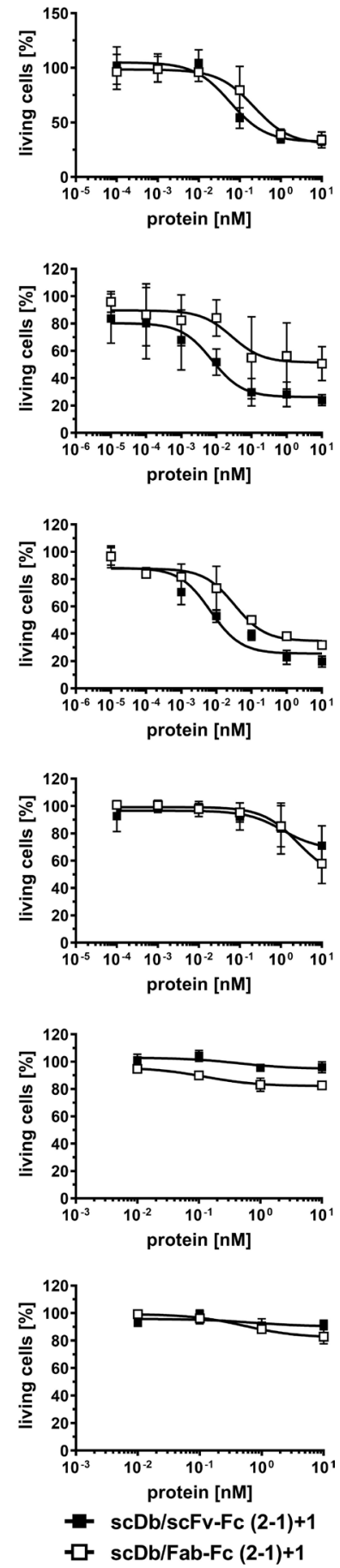

Figure 5 Cytotoxic potential of peripheral blood mononuclear cells (PBMCs) stimulated with scDb/scFv-Fc or scDb/Fab-Fc variants. (A) LIM1215, (B) MCF-7, (C) SKBR-3, (D) FaDu, (E) HT1080 and (F) MDA-MB-231 cells were incubated with a serial dilution of scDb/scFv-Fc or scDb/Fab-Fc variants in the presence of PBMCs in an effector:target cell ratio (E:T) of 10:1. Cell viability was determined using crystal violet staining after 3 days. Mean $\pm S D, n=3$. scDb, single-chain diabody.

scFv-Fc (1-2)+1 and scDb/scFv-Fc (2-1)+1 mediated superior target cell killing compared with the scDb/Fab-Fc in the same configuration on the medium HER3-expressing cell lines (figure $5 \mathrm{~A}-\mathrm{C}$ ). In general, the differences between the $\mathrm{scDb} / \mathrm{scFv}-\mathrm{Fc}$ and the $\mathrm{scDb} / \mathrm{Fab}-\mathrm{Fc}$ format were more pronounced in the (1-2)+1 configuration (13-fold to 88-fold) than in the (2-1)+1 configuration (4-fold to 7-fold) (figure 5A-C, table 3). For the trivalent, bispecific molecules in the (1-1)+2 configuration, a 10 -fold to 40-fold lower cytotoxic capacity compared with the molecules in the (1-2)+1 and (2-1)+1 configuration was observed. Additionally, predominant target cell killing for the $\mathrm{scDb} / \mathrm{scFv}-\mathrm{Fc}(1-1)+2$ compared with the respective $\mathrm{scDb} / \mathrm{Fab}-\mathrm{Fc}$ format was only observed on the MCF-7 cell line (fourfold) while no target cell lysis was observed on the LIM1215 cells with the scDb/scFc-Fc (1-1)+1 and 
Table 3 T-cell mediated killing of tumor cells by scDb/scFv-Fc and scDb/Fab-Fc variants

\begin{tabular}{lllll} 
& LIM1215 & MCF-7 & SKBR-3 & FaDu \\
& $\mathbf{2 0 , 0 0 0 ~ H E R 3 / c e l l ~}$ & $\mathbf{1 8 , 0 0 0}$ HER3/cell & $\begin{array}{l}\mathbf{1 4 , 0 0 0 ~ H E R 3 / c e l l ~} \\
\mathbf{3 0 0 0} \text { HER3/cell }\end{array}$ \\
\hline scDb/scFv-Fc (1-2)+1 & $41 \pm 34$ & $3 \pm 1$ & $3 \pm 2$ & - \\
scDb/Fab-Fc (1-2)+1 & $1544 \pm 1079$ & $233 \pm 89$ & $43 \pm 32$ & - \\
scDb/scFv-Fc (1-1)+2 & - & $688 \pm 600$ & $107 \pm 80$ & - \\
scDb/Fab-Fc (1-1)+2 & - & $2414 \pm 1789$ & $24 \pm 22$ & - \\
scDb/scFv-Fc (2-1)+1 & $65 \pm 30$ & $9 \pm 6$ & $4 \pm 4$ & - \\
scDb/Fab-Fc (2-1)+1 & $238 \pm 165$ & $61 \pm 45$ & $24 \pm 29$ & - \\
\hline
\end{tabular}

$\mathrm{EC}_{50}(\mathrm{pM})$, mean $\pm \mathrm{SD}, \mathrm{n}=3$.

$\mathrm{scDb}$, single-chain diabody.

scDb/Fab-Fc (1-1)+2. Importantly, only a slight cytotoxic effect was observed on the low expression FaDu cell line for all trivalent, bispecific molecules at the highest concentration (figure 5D) while cell viability of the HER3-negative HT1080 and MDA-MB-231 cells remained unaffected (figure 5E,F). Furthermore, analyzing efficacy (maximum target cell lysis at $10 \mathrm{nM}$ trivalent, bispecific antibody) revealed 50\%-80\% killing of LIM1215, MCF-7 and SKBR-3 cells for the molecules in the (1-2)+1 configuration. Treatment with the $\mathrm{scDb} / \mathrm{scFv}-\mathrm{Fc}$ in the $(1-1)+2$ and $(2-1)+1$ configuration led to lysis of $70 \%-85 \%$ of MCF-7 and SKBR-3 cells while the respective scDb/ Fab-Fc molecules only showed 30\%-70\% killing. On the LIM1215 cell line, the molecules in the $(2-1)+1$ configuration showed an efficacy of $70 \%$ while no killing was observed for the (1-1)+2 antibodies.

\section{DISCUSSION}

In this study, we report the generation of novel Fc-comprising trivalent, bispecific antibody molecules capable of redirecting T-cells to HER3-expressing cancer cells. Deploying avidity effects by utilizing a $2+1$ stoichiometry resulted in potent T-cell-engaging trivalent, bispecific antibodies, allowing to differentiate between cells of medium and low HER3 expression.

A critical step of T-cell-mediated eradication of tumor cells is the formation of a tight immune synapse between tumor cell and T-cell. ${ }^{35}$ Here, the close proximity of target and effector cell can be facilitated by the small, compact and rigid scDb format enforcing the formation of a cytolytic synapse similar to bispecific T-cell-engaging tandem scFv molecules (BiTE format). ${ }^{36-38}$ Moreover, our study showed that the molecular geometry and the arrangement of the different binding moieties impact the potency of bispecific antibodies.

For a FynomAb, comparing different geometries by fusing the TAA binders either N-terminally to an antiCD3 mAb or C-terminally to the Fc resulted in a more than 20-fold higher potency for the N-terminal fusion attributed to the favorable closer proximity between TAA and TCR binding. ${ }^{39}$ Similarly, others used a monovalent tumor-targeting IgG scaffold and fused an anti-CD3 scFv to the C-terminus of either the light chain of the TAA arm or the non-targeting binder. ${ }^{40}$ They showed that the fusion to the TAA arm benefits from smaller interdomain spacing resulting in higher in vitro and in vivo potency. In line with this, our data show that positioning the TAA binding sites and the CD3 moiety on opposing arms of the molecule in the (1-1)+2 configuration resulted in more than 30 -fold lower potency in target cell killing.

Additionally, superior target cell killing by the scDb/ scFv-Fc format might also be attributed to the closer proximity of target cell and T-cell due to the smaller scFv compared with the Fab. Furthermore, prior studies have demonstrated that bispecific antibodies targeting epitopes proximal to the membrane elicited more potent T-cell killing compared with those binding distal epitopes. ${ }^{38}{ }^{41-43}$ Targeting membrane-proximal epitopes augments the formation of cytolytic synapses by promoting target clustering and exclusion of the negative regulatory protein CD45 from the immune synapse, ${ }^{42}$ resulting in increased T-cell activation and higher potency in target cell lysis. ${ }^{384142445}$ Accordingly, the potency of the trivalent, bispecific antibodies might not only be attributed to the format, configuration and interdomain spacing but also to the anti-HER3 antibody targeting a membraneproximal epitope. $^{34}$

While the trivalent, bispecific antibodies investigated in this study showed potent killing of HER3-expressing tumor cells, only very low levels of released cytokines were observed. Growing evidence suggests that cytotoxic activity is uncoupled from released cytokines, supported by the definition of two activation thresholds and the expendability of cytokine release for target cell lysis. ${ }^{46}$ While a low number of TCR:peptide-MHC complexes is sufficient to trigger T-cell-mediated target cell killing, a high number of complexes is necessary for cytokine secretion. One explanation could be the separated but intertwined signaling pathways of the TCR differentially regulating release of cytokines and lytic effector molecules. ${ }^{47-49}$ Thus, it has been shown that T-cells maintain their cytolytic activity despite a lack of cytokine release in response to treatment with bispecific T-cell engagers. ${ }^{50}$ 
Moreover, anti-CD3 antibodies have been identified, which, when deployed in a bispecific T-cell-engaging molecule, efficiently kill tumor cells accompanied by minimal cytokine release. ${ }^{47}$ High apparent affinity toward the TAA and a low apparent affinity toward CD3 are not only beneficial for reducing cytokine release but are also important in driving antibody distribution toward the tumor and not to the T-cell compartments, such as bone marrow and lymph nodes. ${ }^{51}$ Avidity-mediated specificity gain through bivalent binding to HER3 combined with monovalent CD3-binding and improved pharmacokinetic properties due to the introduced Fc part presumably should thus result in beneficial safety properties of HER3-targeting T-cell engagers.

Non-clinical safety and tolerability of CD3 bispecific antibodies can be evaluated using studies in pharmacological relevant species, that is, cynomolgus monkey, which might require to substitute the CD3 binding site with that from a cynomolgous CD3-reactive antibody. Possible side effects include cytokine release syndrome (CRS) and neurotoxicity even at low doses. ${ }^{52}$ Therefore, safety and tolerability are rather determined based on the anticipated biological effect not adverse effects. ${ }^{53-55}$

Our results are in accordance with recent findings for an Fc-less trivalent, bispecific $\mathrm{scDb}-\mathrm{scF}$ v fusion protein directed against HER3 and CD3 that, compared with a bivalent bispecific scDb, mediated a strongly increased cytotoxicity toward medium HER3-expressing target cells, which correlated with increased target cell binding, while cytokine release was unaffected. ${ }^{27}$ Thus, cytotoxicity mediated by the best $(1-2)+1 \mathrm{scDb} / \mathrm{scFv}-\mathrm{Fc}$ molecule was only reduced 3-fold to 13-fold to that of the $\mathrm{scDb}$-scFv fusion protein described in the previous study, for example, with an $\mathrm{EC}_{50}$ value of $3 \mathrm{nM}$ for the (1-2)+1 scDb/scFv-Fc and $1 \mathrm{nM}$ for scDb-scFv for MCF-7 and $3 \mathrm{nM}$ vs $41 \mathrm{nM}$ for LIM1215, respectively. ${ }^{27}$ Of note, only medium HER3-expressing cells were lysed by the $(1-2)+1 \mathrm{scDb} / \mathrm{scFv}-\mathrm{Fc}$ molecule, while low HER3-expressing cells remained basically unaffected. This reduction in T-cell-mediated killing by the $\mathrm{scDb} /$ scFv-Fc and scDb/Fab-Fc molecules might be caused by the presence of the Fc-region affecting formation of a tight immunological synapse. In another study, the $2+1$ stoichiometry in a T-cell-dependent bispecific antibody targeting HER2 and CD3 has been shown to increase tumor selectivity by efficiently targeting HER2-positive target cells, while sparing low HER2-expressing cells. ${ }^{22}$ Accordingly, the bivalent binding mode of a carcinoembryonic antigen (CEA)-specific T-cell-engaging bispecific antibody (TCB) translated into selective killing of high CEA-expressing cancer cells while sparing normal epithelial cells resulting in a wide safety window. ${ }^{20}$ Moreover, a correlation between valency and retention time at the tumor was described for a ( $\left.\mathrm{scFv}^{\prime}\right)_{2}$ further showing that valency directly affects tumor localization. ${ }^{56}$ Hence, increased avidity can result in increased selectivity, thus allowing to discriminate between target cells expressing low and medium or high target antigens and consequently may lower the risk of on-target offtumor adverse events. ${ }^{19} 43$
Although the used HER3 antibody (3-43) is crossreactive for murine HER3, the CD3 antibody moiety in the trivalent bispecific molecules derived from UCHT1 does not bind to the murine CD3. Therefore, different strategies could be pursued to evaluate in vivo efficacy of bispecific T-cell-engaging antibodies. Immunodeficient mice engrafted with human tumors ${ }^{57}$ and human immune cells ${ }^{58}$ are a widely used model to study efficacy of T-cell-retargeting antibodies. ${ }^{2059-61}$ In addition to human tumor cell lines, fresh biopsy tissue can be engrafted into immunodeficient mice. ${ }^{62}$ Inoculating human PBMCs into a immunodeficient mouse leads to vigorous response of the human B-cells and T-cells to murine tissue antigen, causing potentially fatal graft versus host disease (GVHD) and severely limits the ability of the human immune cells in their response to exogenous antigen. ${ }^{6364}$ To eliminate the risk of GVHD and to better recapitulate human disease, xenograft models reconstituted with a human hematopoietic system through the engraftment of human cord blood CD $34^{+}$hematopoietic stem cells have been developed. ${ }^{65}$ However, this mouse model is hampered by the maturation of human T-cells in the murine thymus with murine MHC and the lack of human costimulatory molecules. ${ }^{66}{ }^{67}$ Compared with cross-species xenograft models, syngeneic mouse models can offer a more natural tumor environment since mice possess an intact immune system. Additionally, syngeneic models enable the possibility of linger and repeated dosing regimens. However, the use of syngeneic mouse models requires the development of surrogate molecules accurately representing their human analog. ${ }^{68}$ Additionally, murine tumor cells have to be manipulated to express the human antigen bearing the risk of poor engraftment efficacy.

Redirecting T-cells to tumor cells has been reported to be associated with a number of challenges probably limiting or reducing the target cell killing potency, especially in the context of solid tumors. Particularly, disadvantages are associated with the recruitment of naive, exhausted or regulatory T-cells, ${ }^{6970}$ while the tissue-resident memory T-cell phenotype $\left(\mathrm{CD} 8^{+} \mathrm{CD} 69^{+} \mathrm{CD} 103^{+}\right)$has been shown to express high levels of cytotoxic molecules and is associated with a good clinical outcome in cancer. ${ }^{71}$ Central memory T-cells have been shown to mostly traffic to secondary lymphoid tissue and exhibit a high proliferative capacity ${ }^{72}$ whereas T-cells of the effector memory subtype preferentially localize in non-lymphoid tissue and demonstrated a rapid development of effector functions. ${ }^{73} \mathrm{Xu} e t$ $a l^{74}$ demonstrated that the frequency of a T-memory stem cell phenotype in the bulk population of CAR-T-cells positively correlates with their subsequent in vivo expansion. In line with this, treatment with the trivalent, bispecific antibodies used in this study mainly led to the proliferation of central memory (CD45RA $\left.{ }^{-} \mathrm{CCR} 7^{+}\right)$and effector memory (CD45RA $\left.{ }^{-} \mathrm{CCR}^{-}\right) \mathrm{CD}^{+}{ }^{+} \mathrm{T}-\mathrm{cells}$. Additionally, the CD8 ${ }^{+}$T-cell population shifted toward effector or effector memory T-cells, whereas only low proliferation of naive CD8 ${ }^{+}$T-cells was observed. 
The current study demonstrates that the format, geometry and orientation of binding sites influence the potency of bispecific antibodies for T-cell retargeting. For the effective formation of immune synapses resulting in T-cell-mediated tumor cell lysis, the $\mathrm{scDb} / \mathrm{scFv}-\mathrm{Fc}$ format with small interdomain spacing in the (1-2)+1 and (2-1)+1 configuration showed efficient killing of medium HER3expressing cancer cells while sparing target cells with low HER3 expression with an additional preferable safety profile due to low cytokine secretion.

Acknowledgements We would like to thank Nadine Heidel and Sabine Münkel for excellent technical assistance.

Contributors NA, LK and OS performed cloning, protein expression and purification, biochemical analysis, binding studies and bioactivity assays. NA, OS and RK analyzed and interpreted the data. NA, OS and RK were responsible for experimental design and supervised the work. NA, OS and RK wrote the manuscript. All authors read and approved the final manuscript. RK acts as guarantor.

Funding The authors have not declared a specific grant for this research from any funding agency in the public, commercial or not-for-profit sectors.

Competing interests NA, OS and RK are named inventors on patent applications covering the HER3 antibody and scDb-based T-cell engagers.

Patient consent for publication Not applicable.

Provenance and peer review Not commissioned; externally peer reviewed.

Data availability statement Data are available upon reasonable request.

Supplemental material This content has been supplied by the author(s). It has not been vetted by BMJ Publishing Group Limited (BMJ) and may not have been peer-reviewed. Any opinions or recommendations discussed are solely those of the author(s) and are not endorsed by BMJ. BMJ disclaims all liability and responsibility arising from any reliance placed on the content. Where the content includes any translated material, BMJ does not warrant the accuracy and reliability of the translations (including but not limited to local regulations, clinical guidelines, terminology, drug names and drug dosages), and is not responsible for any error and/or omissions arising from translation and adaptation or otherwise.

Open access This is an open access article distributed in accordance with the Creative Commons Attribution Non Commercial (CC BY-NC 4.0) license, which permits others to distribute, remix, adapt, build upon this work non-commercially, and license their derivative works on different terms, provided the original work is properly cited, appropriate credit is given, any changes made indicated, and the use is non-commercial. See http://creativecommons.org/licenses/by-nc/4.0/.

\section{ORCID iD}

Roland E Kontermann http://orcid.org/0000-0001-7139-1350

\section{REFERENCES}

1 Campbell MR, Amin D, Moasser MM. HER3 comes of age: new insights into its functions and role in signaling, tumor biology, and cancer therapy. Clin Cancer Res 2010;16:1373-83.

2 Ocana A, Vera-Badillo F, Seruga B, et al. HER3 overexpression and survival in solid tumors: a meta-analysis. J Natl Cancer Inst 2013;105:266-73.

3 Kruser TJ, Wheeler DL. Mechanisms of resistance to HER family targeting antibodies. Exp Cell Res 2010;316:1083-100.

4 Leto SM, Sassi F, Catalano I, et al. Sustained inhibition of HER3 and EGFR is necessary to induce regression of HER2-amplified gastrointestinal carcinomas. Clin Cancer Res 2015;21:5519-31.

5 Zhang X, Wen L, Chen S, et al. The novel long noncoding RNA CRART16 confers cetuximab resistance in colorectal cancer cells by enhancing ERBB3 expression via miR-371a-5p. Cancer Cell Int 2020;20:68.

6 Malm M, Frejd FY, Ståhl S, et al. Targeting HER3 using monoand bispecific antibodies or alternative scaffolds. MAbs 2016;8:1195-209.

7 Jacob W, James I, Hasmann M, et al. Clinical development of HER3targeting monoclonal antibodies: perils and progress. Cancer Treat Rev 2018;68:111-23.
8 Haikala HM, Jänne PA. Thirty years of HER3: from basic biology to therapeutic interventions. Clin Cancer Res 2021;27:3528-3539.

9 Forster MD, Dillon MT, Kocsis J, et al. Patritumab or placebo, with cetuximab plus platinum therapy in recurrent or metastatic squamous cell carcinoma of the head and neck: a randomised phase II study. Eur J Cancer 2019;123:36-47.

10 Sequist LV, Gray JE, Harb WA, et al. Randomized phase II trial of seribantumab in combination with erlotinib in patients with EGFR wild-type non-small cell lung cancer. Oncologist 2019;24:1095-102.

11 Hill AG, Findlay MP, Burge ME, et al. Phase II study of the dual EGFR/HER3 inhibitor duligotuzumab (MEHD7945A) versus cetuximab in combination with FOLFIRI in second-line RAS wild-type metastatic colorectal cancer. Clin Cancer Res 2018;24:2276-84.

12 Bourillon L, Bourgier C, Gaborit N, et al. An auristatin-based antibody-drug conjugate targeting HER3 enhances the radiation response in pancreatic cancer. Int J Cancer 2019;145:1838-51.

13 Koganemaru S, Kuboki Y, Koga Y, et al. U3-1402, a novel HER3targeting antibody-drug conjugate, for the treatment of colorectal cancer. Mol Cancer Ther 2019;18:2043-50.

14 D'Agostino D, Gentile R, Ponziani S, et al. EV20-sss-vc/MMAF, an HER-3 targeting antibody-drug conjugate displays antitumor activity in liver cancer. Oncol Rep 2021;45:776-85.

15 Brinkmann U, Kontermann RE. Bispecific antibodies. Science 2021;372:916-7.

16 Middelburg J, Kemper K, Engelberts P, et al. Overcoming challenges for CD3-bispecific antibody therapy in solid tumors. Cancers 2021;13 doi:10.3390/cancers13020287

17 Kobold S, Pantelyushin S, Rataj F, et al. Rationale for combining bispecific $T$ cell activating antibodies with checkpoint blockade for cancer therapy. Front Oncol 2018;8:285.

18 Goebeler M-E, Bargou R. Blinatumomab: a CD19/CD3 bispecific T cell engager (BiTE) with unique anti-tumor efficacy. Leuk Lymphoma 2016;57:1021-32.

19 Vauquelin G, Charlton SJ. Exploring avidity: understanding the potential gains in functional affinity and target residence time of bivalent and heterobivalent ligands. Br J Pharmacol 2013;168:1771-85.

20 Bacac M, Fauti T, Sam J, et al. A novel carcinoembryonic antigen Tcell bispecific antibody (CEA TCB) for the treatment of solid tumors. Clin Cancer Res 2016;22:3286-97.

21 Seckinger A, Delgado JA, Moser S, et al. Target expression, generation, preclinical activity, and pharmacokinetics of the BCMA-T cell bispecific antibody EM801 for multiple myeloma treatment. Cancer Cell 2017;31:396-410.

22 Slaga D, Ellerman D, Lombana TN, et al. Avidity-based binding to HER2 results in selective killing of HER2-overexpressing cells by anti-HER2/CD3. Sci Transl Med 2018;10 doi:10.1126/scitranslmed. aat5775

23 Yoon A, Lee S, Lee S, et al. A novel T Cell-engaging bispecific antibody for treating mesothelin-Positive solid tumors. Biomolecules 2020;10:399. doi:10.3390/biom10030399

24 Segal DM, Weiner GJ, Weiner LM. Bispecific antibodies in cancer therapy. Curr Opin Immunol 1999;11:558-62.

25 Husain B, Ellerman D. Expanding the boundaries of biotherapeutics with bispecific antibodies. BioDrugs 2018;32:441-64.

26 Bardwell PD, Staron MM, Liu J, et al. Potent and conditional redirected T cell killing of tumor cells using half DVD-Ig. Protein Cell 2018;9:121-9.

27 Aschmoneit N, Steinlein S, Kühl L, et al. A scDb-based trivalent bispecific antibody for T-cell-mediated killing of HER3-expressing cancer cells. Sci Rep 2021;11:13880.

28 Mack M, Riethmüller G, Kufer P. A small bispecific antibody construct expressed as a functional single-chain molecule with high tumor cell cytotoxicity. Proc Natl Acad Sci U S A 1995;92:7021-5.

29 Johnson S, Burke S, Huang L, et al. Effector cell recruitment with novel Fv-based dual-affinity re-targeting protein leads to potent tumor cytolysis and in vivo B-cell depletion. $\mathrm{J} \mathrm{Mol} \mathrm{Biol}$ 2010;399:436-49.

30 Korn T, Müller R, Kontermann RE. Bispecific single-chain diabodymediated killing of endoglin-positive endothelial cells by cytotoxic $T$ lymphocytes. J Immunother 2004;27:99-106.

31 Stieglmaier J, Benjamin J, Nagorsen D. Utilizing the BiTE (bispecific T-cell engager) platform for immunotherapy of cancer. Expert Opin Biol Ther 2015;15:1093-9.

32 Wu J, Fu J, Zhang M, et al. Blinatumomab: a bispecific T cell engager (BiTE) antibody against CD19/CD3 for refractory acute lymphoid leukemia. J Hematol Oncol 2015;8:104.

33 Merchant AM, Zhu Z, Yuan JQ, et al. An efficient route to human bispecific IgG. Nat Biotechnol 1998;16:677-81. 
34 Schmitt LC, Rau A, Seifert O, et al. Inhibition of HER3 activation and tumor growth with a human antibody binding to a conserved epitope formed by domain III and IV. MAbs 2017;9:831-43.

35 de la Roche M, Asano Y, Griffiths GM. Origins of the cytolytic synapse. Nat Rev Immunol 2016;16:421-32.

36 Offner S, Hofmeister R, Romaniuk A, et al. Induction of regular cytolytic $T$ cell synapses by bispecific single-chain antibody constructs on MHC class I-negative tumor cells. Mol Immunol 2006;43:763-71.

37 Strohl WR, Naso M. Bispecific T-cell redirection versus chimeric antigen receptor (CAR)-T cells as approaches to kill cancer cells. Antibodies 2019;8:41. doi:10.3390/antib8030041

38 Chen W, Yang F, Wang C, et al. One size does not fit all: navigating the multi-dimensional space to optimize T-cell engaging protein therapeutics. MAbs 2021:13:1871171.

39 Wuellner U, Klupsch K, Buller F, et al. Bispecific CD3/HER2 targeting FynomAb induces redirected $\mathrm{T}$ cell-mediated cytolysis with high potency and enhanced tumor selectivity. Antibodies 2015;4:426-40.

40 Santich BH, Park JA, Tran H, et al. Interdomain spacing and spatial configuration drive the potency of IgG-[L]-scFv T cell bispecific antibodies. Sci Trans/ Med 2020;12 doi:10.1126/scitransImed. aax 1315

41 Bluemel C, Hausmann S, Fluhr P, et al. Epitope distance to the target cell membrane and antigen size determine the potency of $T$ cell-mediated lysis by BiTE antibodies specific for a large melanoma surface antigen. Cancer Immunol Immunother 2010;59:1197-209.

42 Li J, Stagg NJ, Johnston J, et al. Membrane-proximal epitope facilitates efficient $\mathrm{T}$ cell synapse formation by Anti-FcRH5/ $\mathrm{CD} 3$ and is a requirement for myeloma cell killing. Cancer Cell 2017;31:383-95.

43 Ellerman D. Bispecific T-cell engagers: towards understanding variables influencing the in vitro potency and tumor selectivity and their modulation to enhance their efficacy and safety. Methods 2019:154:102-17.

44 Qi J, Li X, Peng H, et al. Potent and selective antitumor activity of a T cell-engaging bispecific antibody targeting a membrane-proximal epitope of ROR1. Proc Natl Acad Sci U S A 2018;115:E5467-76.

45 Nair-Gupta P, Diem M, Reeves D, et al. A novel C2 domain binding CD33xCD3 bispecific antibody with potent T-cell redirection activity against acute myeloid leukemia. Blood Adv 2020;4:906-19.

46 Faroudi M, Utzny C, Salio M, et al. Lytic versus stimulatory synapse in cytotoxic T lymphocyte/target cell interaction: manifestation of a dual activation threshold. Proc Natl Acad Sci U S A 2003;100:14145-50.

47 Trinklein ND, Pham D, Schellenberger U, et al. Efficient tumor killing and minimal cytokine release with novel T-cell agonist bispecific antibodies. MAbs 2019;11:639-52.

48 Gaud G, Lesourne R, Love PE. Regulatory mechanisms in T cell receptor signalling. Nat Rev Immunol 2018;18:485-97.

49 Brownlie RJ, Zamoyska R. T cell receptor signalling networks: branched, diversified and bounded. Nat Rev Immunol 2013;13:257-69.

50 Li J, Piskol R, Ybarra R, et al. CD3 bispecific antibody-induced cytokine release is dispensable for cytotoxic T cell activity. Sci Trans/ Med 2019;11 doi:10.1126/scitranslmed.aax8861

51 Mandikian D, Takahashi N, Lo AA, et al. Relative target affinities of T-cell-dependent bispecific antibodies determine biodistribution in a solid tumor mouse model. Mol Cancer Ther 2018;17:776-85.

52 Schaller TH, Snyder DJ, Spasojevic I, et al. First in human dose calculation of a single-chain bispecific antibody targeting glioma using the MABEL approach. J Immunother Cancer 2020;8.

53 Dudal S, Hinton H, Giusti AM, et al. Application of a MABEL approach for a T-Cell-Bispecific monoclonal antibody: CEA TCB. $J$ Immunother 2016;39:279-89.
54 Horvath C, Andrews L, Baumann A, et al. Storm forecasting: additional lessons from the CD28 superagonist TGN1412 trial. Nat Rev Immunol 2012;12:740.

55 Hünig T. The storm has cleared: lessons from the CD28 superagonist TGN1412 trial. Nat Rev Immunol 2012;12:317-8.

56 Adams GP, Tai M-S, McCartney JE, et al. Avidity-mediated enhancement of in vivo tumor targeting by single-chain Fv dimers. Clin Cancer Res 2006;12:1599-605.

57 Reddy S, Piccione D, Takita H, et al. Human lung tumor growth established in the lung and subcutaneous tissue of mice with severe combined immunodeficiency. Cancer Res 1987;47:2456-60.

58 Mosier DE, Gulizia RJ, Baird SM, et al. Transfer of a functional human immune system to mice with severe combined immunodeficiency. Nature 1988;335:256-9.

59 DiLillo DJ, Olson K, Mohrs K, et al. A BCMAxCD3 bispecific T cellengaging antibody demonstrates robust antitumor efficacy similar to that of anti-BCMA CAR T cells. Blood Adv 2021;5:1291-304.

60 Staflin K, Zuch de Zafra CL, Schutt LK, et al. Target arm affinities determine preclinical efficacy and safety of anti-HER2/CD3 bispecific antibody. JCl Insight 2020;5 doi:10.1172/jci.insight.133757

61 Friedrich M, Henn A, Raum T, et al. Preclinical characterization of AMG 330, a CD3/CD33-bispecific T-cell-engaging antibody with potential for treatment of acute myelogenous leukemia. Mol Cancer Ther 2014;13:1549-57.

62 Williams SS, Alosco TR, Croy BA, et al. The study of human neoplastic disease in severe combined immunodeficient mice. Lab Anim Sci 1993;43:139-46.

63 Tary-Lehmann M, Saxon A. Human mature T cells that are anergic in vivo prevail in SCID mice reconstituted with human peripheral blood. $J$ Exp Med 1992;175:503-16.

64 Williams SS, Umemoto T, Kida H, et al. Engraftment of human peripheral blood leukocytes into severe combined immunodeficient mice results in the long term and dynamic production of human xenoreactive antibodies. J Immunol 1992;149:2830-6.

65 Ishikawa F, Yasukawa M, Lyons B, et al. Development of functional human blood and immune systems in NOD/SCID/IL2 receptor \{gamma\} chain(null) mice. Blood 2005;106:1565-73.

66 Yin L, Wang X-J, Chen D-X, et al. Humanized mouse model: a review on preclinical applications for cancer immunotherapy. Am J Cancer Res 2020;10:4568-84.

67 Watanabe Y, Takahashi T, Okajima A, et al. The analysis of the functions of human $B$ and T cells in humanized NOD/shi-scid/ gammac(null) (NOG) mice (hu-HSC NOG mice). Int Immunol 2009;21:843-58.

68 Wang F, Tsai JC, Davis JH, et al. Design and characterization of mouse IgG1 and IgG2a bispecific antibodies for use in syngeneic models. MAbs 2020;12:1685350.

69 Golubovskaya V, Wu L. Different subsets of T cells, memory, effector functions, and CAR-T immunotherapy. Cancers 2016;8 doi:10.3390/ cancers 8030036

70 Chraa D, Naim A, Olive D, et al. T lymphocyte subsets in cancer immunity: friends or foes. J Leukoc Biol 2019;105:243-55.

71 Blanc C, Hans S, Tran T, et al. Targeting resident memory T cells for cancer immunotherapy. Front Immunol 2018;9:9.

72 Klebanoff CA, Gattinoni L, Torabi-Parizi P, et al. Central memory self/ tumor-reactive CD8+ T cells confer superior antitumor immunity compared with effector memory T cells. Proc Natl Acad Sci U S A 2005;102:9571-6.

73 Manjunath N, Shankar P, Wan J, et al. Effector differentiation is not prerequisite for generation of memory cytotoxic T lymphocytes. $J$ Clin Invest 2001:108:871-8.

74 Xu Y, Zhang M, Ramos CA, et al. Closely related T-memory stem cells correlate with in vivo expansion of CAR.CD19-T cells and are preserved by IL-7 and IL-15. Blood 2014;123:3750-9. 